\title{
Relative Positions of the Thermal Convection Column and Smoke Plume Generated from a Smoldering Cigarette*
}

by

Douglas D. McRae and Robert W. Jenkins, Jr.

Philip Morris U.S.A.,

Research and Development,

P.O. Box 26583,

Richmond, VA 23261, U.S.A.

\section{SUMMARY}

The relative positions of the thermal convection column and the smoke plume from a variety of smoldering cigarettes were measured using a combination of schlieren and visual optical systems. The schlieren technique is an optical method used to observe refractive index gradients in gases and other clear media. The refractive index gradients can be caused by variations in pressure, composition or temperature. The convection column of heated air and combustion gases rising from a cigarette coal was observed with a two mirror schlieren system. A video camera was used as the observing device rather than the usual photographic camera. A second video camera was arranged to view the smoke plume rising from the coal region. The two video images were combined with a video special effects generator and were viewed on a single monitor. The behavior and relative positions of both columns were thus observed in real time with two noninvasive optical methods. The schlieren images of the convection column were compared to those of model systems such as a heated cylinder and a small flame. Results for experimental cigarettes with paper porosities of $12 \mathrm{~cm} / \mathrm{min}$ to $48 \mathrm{~cm} / \mathrm{min}$ (CORESTA) during smolder showed that the thermal convection column was centered $2 \mathrm{~mm}$ to $3 \mathrm{~mm}$ in front of the paper char line directly over the hottest part of the coal as determined by infrared imaging. The smoke plume was centered $2 \mathrm{~mm}$ behind the paper char line and the position did not change with paper porosity. Results for experimental cigarettes made with a commercially available low sidestream paper showed that

\footnotetext{
* Received: 3rd July 1990 - accepted 26th September 1991
}

the position of the convection column did not change. However, the position of the smoke plume changed considerably. In addition to being markedly decreased in visibility, the plume now appeared to be centered directly over the paper char line. This change in position provides a valuable insight into the mechanism of smoke reduction. The low sidestream papers seem to work by preventing the escape of smoke forming condensibles through the paper behind the paper char line. The condensibles are therefore forced to escape at the paper char line and undergo increased combustion and pyrolysis. As a result, some are converted to lower molecular weight materials and are unable to condense as readily to form the smoke. In addition, the remaining condensibles are released into a hotter and faster rising gas stream. This serves to reduce smoke formation by suppressing condensation and increasing dilution.

\section{RESUME}

En utilisant une combinaison de systèmes optiques strioscopique et visuel, on a mesuré les positions relatives de la colonne de convection thermique et du panache de fumée produit par diverses cigarettes en train de se consumer. La technique strioscopique est une méthode optique utilisée pour observer les gradients des indices de réfraction dans les gaz et d'autres milieux transparents. Les gradients des indices de réfraction peuvent être dus à des variations de pression, de composition ou de température. La colonne de convection de l'air chaud et des gaz de combustion issus d'une cigarette carbonisée a été étudiée à l'aide d'un 
système strioscopique à deux miroirs. Pour l'observation, on a préféré une caméra vidéo à l'appareil photographique généralement utilisé. Une seconde caméra vidéo était disposée de manière à permettre d'examiner le panache de fumée s'élevant de la zone carbonisée. Les deux images vidéo ont été combinées avec un générateur d'effets spéciaux et visionnées sur un écran unique. Le comportement et les positions relatives des deux colonnes ont ainsi été observés en temps réel à l'aide de deux méthodes optiques de type «non-invasive». Les images strioscopiques de la colonne de convection ont été comparées à celles de systèmes modèles tels qu'un cylindre chauffé et une petite flamme. Les résultats obtenus avec des cigarettes expérimentales dont le papier avait une porosité allant de 12 à $48 \mathrm{~cm} / \mathrm{min}$ (CORESTA) pendant la combustion ont montré que la colonne de convection thermique était centrée à 2 ou $3 \mathrm{~mm}$ en face de la ligne de carbonisation du papier, directement au dessus de la zone la plus chaude du charbon déterminée par détection infra-rouge. Le panache de fumée était centré à $2 \mathrm{~mm}$ en arrière de la ligne de carbonisation du papier, cette position étant indépendante de la porosité du papier. Les résultats obtenus avec des cigarettes expérimentales confectionnées avec un papier existant sur le marché et conçu pour réduire la quantité de fumée secondaire produite pendant la combustion ont montré que la position de la colonne de convection restait la même alors que celle du panache de fumée changeait considérablement. Non seulement le panache était nettement moins visible, mais il apparaissait maintenant directement centré au-dessus de la ligne de carbonisation du papier. Ce changement de position fournit un précieux indice sur le mécanisme de réduction de la fumée. Les papiers diminuant la quantité de fumée secondaire semblent agir en empêchant les substances condensables formant la fumée de quitter la cigarette en arrière de la ligne de carbonisation du papier. Ces substances sont donc forcées de s'échapper au niveau de la ligne de carbonisation et subissent une combustion et une pyrolyse accrues. Il en résulte que certaines sont transformées en produits à plus faible poids moléculaire et ne sont pas à même de condenser aussi facilement pour former la fumée. De plus, les substances condensables restantes sont libérées dans un courant de gaz plus chaud et plus rapide. Ceci sert à réduire la formation de fumée en supprimant la condensation et en augmentant la dilution. ten Mediums entstehen. Die Konvektionssäule erhitzter Luft sowie Verbrennungsgase über den Glutkegeln wurden mit einem aus zwei Spiegeln bestehenden Schlierensystem analysiert. Als Beobachtungsgerät wurde eine Videokamera und nicht der sonst übliche Photoapparat verwendet. Mit einer zweiten Videokamera wurde der von der Glutzone ausgehende Wirbel beobachtet. Die beiden Videobilder wurden mit Hilfe eines Trickmischers miteinander kombiniert und auf einem Monitor sichtbar gemacht. Veränderungen und die relative Position beider Ströme wurden in Echtzeit mit zwei nicht-invasiven optischen Methoden beobachtet. Die Schlierenbilder der Konvektionsströme wurden mit Bildern von Modellsystemen verglichen, und zwar einem erwärmten Zylinder und einer kleinen Flamme. Infrarotaufnahmen zeigten, daß sich bei experimentellen Cigaretten mit einer Papierporosität von $12 \mathrm{~cm} / \mathrm{min}$ bis $48 \mathrm{~cm} / \mathrm{min}$ (CORESTA) während des Glimmens die thermischen Konvektionsströme 2-3 mm vor der Brennlinie des Papiers, direkt über dem heißesten Punkt der Glutzone, zentrierten. Der Wirbel befand sich $2 \mathrm{~mm}$ hinter der Verkohlungsgrenzlinie des Papiers und die Position änderte sich mit veränderter Papierporosität nicht. Die Ergebnisse für experimentelle Cigaretten mit einem handelsüblichen Spezialpapier zur Senkung der Nebenstromrauchausbeute zeigten, daß die Position des Konvektionsstroms sich nicht änderte. Die Position des Rauchwirbels jedoch änderte sich beträchtlich. Sie war nicht nur weniger sichtbar, sondern schien nun direkt über der Verkohlungsgrenzlinie des Papiers zentriert. Diese Positionsänderung gibt einen nützlichen Einblick in die Mechanismen der Rauchreduzierung. Spezialpapier zur Verminderung des Nebenstromrauches scheint zu wirken, indem der Austritt von kondensierbaren Anteilen durch das Papier verhindert wird. Diese kondensierbaren Anteile müssen an der Grenzlinie entweichen und werden somit stärker verbrannt und pyrolysiert. Als Ergebnis wird ein Teil in niedermolekulare Komponenten zerlegt und kann zur Rauchkondensation nicht beitragen. Zusätzlich treten die verbleibenden kondensierbaren Partikel in einen heißen und schneller aufsteigenden Gasstrom über. Dies dient dazu, die Rauchbildung zu verringern, indem die Kondensation unterdrückt und die Verdünnung erhöht wird.

\section{INTRODUCTION}

The schlieren technique is an optical method used to observe refractive index gradients in gases, especially air, and other clear media. The refractive index gradients can be caused by pressure, composition and temperature differences. An example of the gradients caused by pressure differences would be the shock waves formed from an object travelling at high velocity. Most people are familiar with the schlieren image of a bullet showing these shock waves. An example of gradients caused by compositional differences would be a jet of gas expanding into another gas of different refractive index. Similarly, the 
convection currents formed over a heated object are visible with the schlieren technique because the heated air has a lower density and, hence, a lower refractive index. In this work a schlieren system was used as a non-invasive method to observe the thermal convection column rising from a cigarette coal while the smoke plume was observed directly. The specific goal was to study the relative positions of the two columns and to compare the shape of the convection column with model systems. Researchers have long taken interest in both aspects of the sidestream from cigarettes. There were a number of papers in the early to mid-sixties that sought to define the various smoke streams coming from a cigarette (1-3). NEURATH et al. made one of the earlier measurements of the temperature contours above a smoldering cigarette (4). This paper is also the source for the frequently quoted value for the rise velocity of the smoke plume, $33 \mathrm{~cm} / \mathrm{sec}$. AYER and YEAGER reported a value of $20 \mathrm{~cm} / \mathrm{sec}$ for the rise velocity (5).BAKER published a frequently cited paper that reported the temperature contours and concentration profiles for several gases above the cigarette coal (6). He also observed that the convection column is centered 3-4 $\mathrm{mm}$ in front of the paper char line while the smoke plume is centered 3-5 $\mathrm{mm}$ behind the paper char line. Recently, RoBINSON reported the complete three dimensional velocity profiles above a coal using a laser doppler velocimeter (7). $\mathrm{He}$ found that there was a convection column of nearly particle free gas centered $2 \mathrm{~mm}$ in front of the paper char line. The shape of the velocity profile showed a peak at this location with the velocity decreasing symmetrically as one moved away from this point. The maximum upward velocity of this column $1 \mathrm{~cm}$ above the coal was $41.5 \mathrm{~cm} / \mathrm{sec}$. This accelerated to $65 \mathrm{~cm} / \mathrm{sec}$ at $5 \mathrm{~cm}$ above the coal. The visible smoke plume was centered $2 \mathrm{~mm}$ behind the paper char line and had particulate concentrations of $10 \% / \mathrm{cm}^{3}$. The values for the velocity of the smoke plume are in good agreement with earlier values with $20 \mathrm{~cm} / \mathrm{sec}$ occurring at $1 \mathrm{~cm}$ above the cigarette and $33 \mathrm{~cm} / \mathrm{sec}$ at $2.5 \mathrm{~cm}$.

\section{EXPERIMENTAL}

The schlieren system used in this work was a two mirror system shown in Figure $1(8,9)$. The following description closely parallels that found in Reference 8 and interested readers are encouraged to consult this pamphlet. The entire system was assembled on a $4 \times 6 \mathrm{ft}^{*}$ optical table (Newport Corp., Fountain Valley, CA, U.S.A.). Light from a 50 watt tungsten-halogen lamp in a Newport Corp. housing was focused by an f/2 100-mm camera lens (Olympus Corp., Woodbury, NY, U.S.A.) onto the first knife edge positioned to intercept about half of the light. The knife edge was a razor blade located one focal length (48 inches) $* *$ away from an 8-inch, $\mathrm{f} / 6$ parabolic mirror (Parks Telescope Co., Simi Vallay, CA, U.S.A.). After the first knife edge, the light fell on this first mirror and was reflected across the optical table as a parallel beam 8 inches
Figure 1.

Two mirror schlieren system.

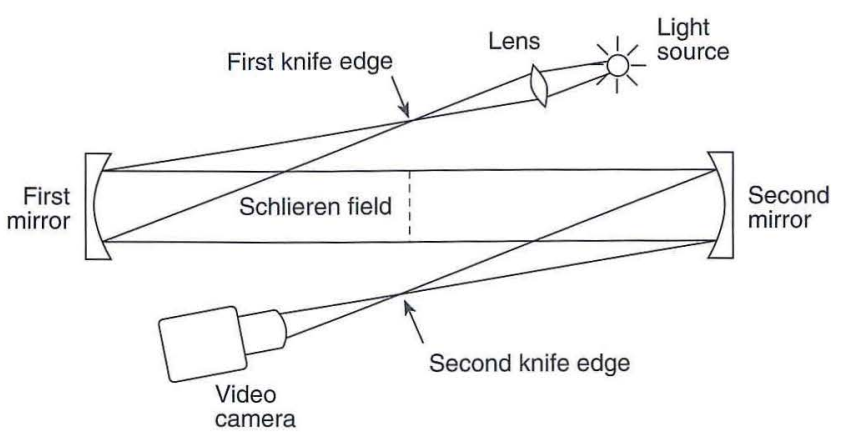

in diameter to a second, identical mirror. The second mirror refocused the light to a small spot and, at this point, a second razor blade parallel to the first was partially inserted into the spot to create a gate. The final schlieren image was viewed directly with an RCA TC1005 video camera (RCA Closed-Circuit Video Equipment, Lancaster, PA, U.S.A.) equipped with an Olympus $\mathrm{f} / 2.8 \quad 100-\mathrm{mm}$ lens. A Lexan ${ }^{\circledR}$ enclosure was placed over the schlieren system to shield it from drafts in the laboratory.

The region between the two mirrors is called the schlieren field. In the schlieren field any gradient in the refractive index of the air causes a change in the image seen due to the refraction of the light passing through the gradient. In the absence of refractive index gradients, the amount of light seen by the video camera is determined by the position of the two razor blades. Solid objects in the schlieren field appear as a silhouette. When a refractive index gradient exists normal to the razor blades, the gradient bends the light rays passing through it (refraction) so that the rays are intercepted by the second razor blade to a greater extent (darker image where the gradient exists) or lesser extent (brighter image where the gradient exists). This system was designed to view the thermal convection column rising from a cigarette coal. The gradients that will form the image of this vertical column are in the horizontal direction. Therefore, the razor blades were set with the knife edges in a vertical orientation so that they would be normal to the gradients of interest. The sensitivity of the schlieren system could be adjusted by changing the position of the second razor blade in the focused spot of light. By moving the razor blade further into the spot of light so that almost all of the light is intercepted, the system can easily detect refractive index gradients caused by temperature differences of a few degrees Celsius. For example, one could observe the convection currents rising from a person's hand. The sensitivity of the system was usually set lower because the

\footnotetext{
* 1 foot $=3.048 \times 10^{-1} \mathrm{~m}=30.48 \mathrm{~cm}$

$\because 1$ inch $=2.54 \times 10^{-2} \mathrm{~m}=25.4 \mathrm{~mm}$
} 
air temperature differences present in the thermal column rising from a cigarette coal are much larger.

An interesting effect of the lamp orientation was noted when the schlieren system was being assembled. The 50 watt tungsten-halogen lamp has a wound filament approximately $3 \mathrm{~mm}$ long by $1 \mathrm{~mm}$ high. If the lamp was positioned so the long dimension of the filament was perpendicular to the knife edges, as it would be if the lamp housing was in the usual upright position with the razor blades placed vertically, the schlieren image had a number of shimmering striations in the light intensity. The striations were caused by the filament wire which, because of the windings, were actually parallel to the knife edges in this position. The shimmering effect was probably caused by vibrations in the filament. Remounting the lamp housing sideways eliminated the problem.

The schlieren image is formed behind the second razor blade and can be viewed directly on a screen. The image is usually recorded with a photographic camera; however, for this work a video camera was used. The major advantage of using a video camera was that the dynamic schlieren image could be recorded on video tape for analysis. In addition, a second RCA video camera was used to observe the visible smoke plume. The second

\section{Figure 2.}

Schlieren image of a jet of methane gas exiting a 17 gauge blunt hypodermic needle. The center of the gas jet is indicated by the line separating the dark and bright halves of the jet's image. camera was placed just over the first mirror and directly viewing the cigarette placed in the schlieren field. Image size of the cigarette was adjusted with a zoom lens (Olympus Corp.) to match the size of the silhouette of the cigarette in the schlieren image. The visibility of the smoke plume for the second camera was enhanced by illuminating the plume with an intense beam of light from nearly opposite the second camera. The light scattered from small particles is most intense in the forward direction (the direction of travel of the beam of light). The camera could not view the light source without being blinded so the light beam had to just miss the camera. This arrangement made the smoke plume show up clearly against a black background. The placement of this smoke illumination lamp had the added effect of illuminating the cigarette in the schlieren image so that it did not appear solely as a silhouette and the paper char line was clearly visible. The images from the two cameras were combined using a Panasonic WJ-4600B special effects generator (Panasonic Industrial Co., Secaucus, NJ, U.S.A.). The special effects generator synchronized the two cameras and inserted a section of the image from the first camera

Figure 3.

Schlieren image of a small gas flame. The gas jet in Figure 2 has been lit for this picture.

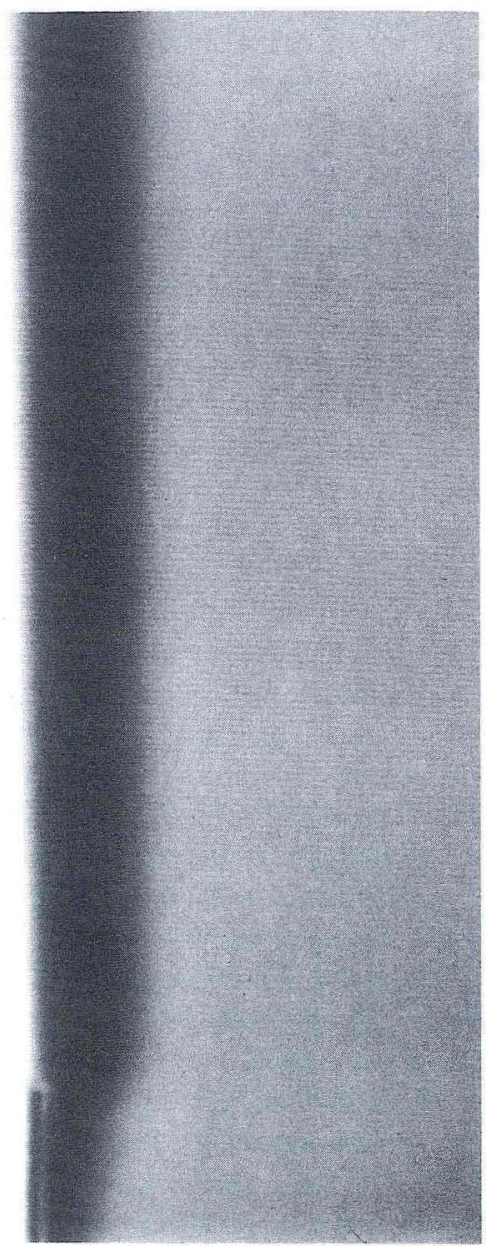


into the image of the second camera. Thus, the final image appeared as a split image with one side showing the schlieren image and the other side showing the smoke plume. The combined image was then passed through a Panasonic WJ-810 video timer which placed the date and time in the image. The final image was displayed on a high resolution video monitor and was recorded on a Sony VO-5800H (Sony Corp., Tokyo, Japan) video cassette recorder.

The cigarettes observed with the schlieren system were 2R1 Kentucky Research reference cigarettes and two series of experimental cigarettes. One series had paper porosities of $12 \mathrm{~cm} / \mathrm{min}$ (nonporous), $23 \mathrm{~cm} / \mathrm{min}$ and $48 \mathrm{~cm} / \mathrm{min}$ (porous) (CORESTA) with $0.8 \%$ citrate added while the other series was made with a commercially available paper designed to reduce the amount of sidestream smoke produced during smolder. This paper had a $\mathrm{Mg}(\mathrm{OH})_{2}$ based inorganic filler and a porosity of $17 \mathrm{~cm} /$ min (CORESTA). All cigarettes had a circumference of approximately $24 \mathrm{~mm}$ and were conditioned at $60 \%$ relative humidity and $23{ }^{\circ} \mathrm{C}$ before smoking. The cigarettes were allowed to smolder freely with no puffs being taken except for a lighting puff. The cigarettes were marked on the paper at $20 \mathrm{~mm}$ and $40 \mathrm{~mm}$ from the lighting end. This allowed a precise indication in the visual image of when the paper char line reached these points. Thin wire pointers supported from below the cigarette were used to show the $20 \mathrm{~mm}$ and $40 \mathrm{~mm}$ points in the schlieren image.

Two models were used for comparison with the cigarette images. The first was a ceramic cylinder $8 \mathrm{~mm}$ in diameter and $103 \mathrm{~mm}$ in length. The cylinder was heated with an internal nichrome wire heating element controlled by a variable voltage transformer. The second model was a methane gas jet exiting a 17 gauge blunt hypodermic needle. The gas flow was set at a very low rate and the jet was observed both lit and unlit. When lit, the gas jet burned with a small, nearly spherical flame $3 \mathrm{~mm}$ to $4 \mathrm{~mm}$ high.

\section{RESULTS AND DISCUSSION}

The fact that the schlieren method detects refractive index gradients results in a particularly useful property in the schlieren image. The center of a thermal convection column or gas jet appears as a relatively sharp line separating the two halves of the column image. This effect is clearly shown in Figures 2 and 3 for an unlit jet of methane and the same jet lit, respectively. In both cases one half of the schlieren image is brighter having had light refracted into this region of the image. The other half is darker having had light refracted out. Notice that the dark and bright sides of the image are reversed in the unlit methane gas jet image compared with those in the lit image. This is because the methane gas has a higher refractive index than air at room temperature while the heated gases and air from the flame have a lower refractive index. For this particular schlieren system the knife edges are set so that when the refractive index is decreasing going from right to left in the image, light is refracted into the image and this area appears brighter. The opposite occurs when the refractive index is increasing and, as a result, this region appears darker. At the point where the

Figure 4.

Side view of a heated cylinder taken with the schlieren system. The thermal convection currents in the air are clearly visible.

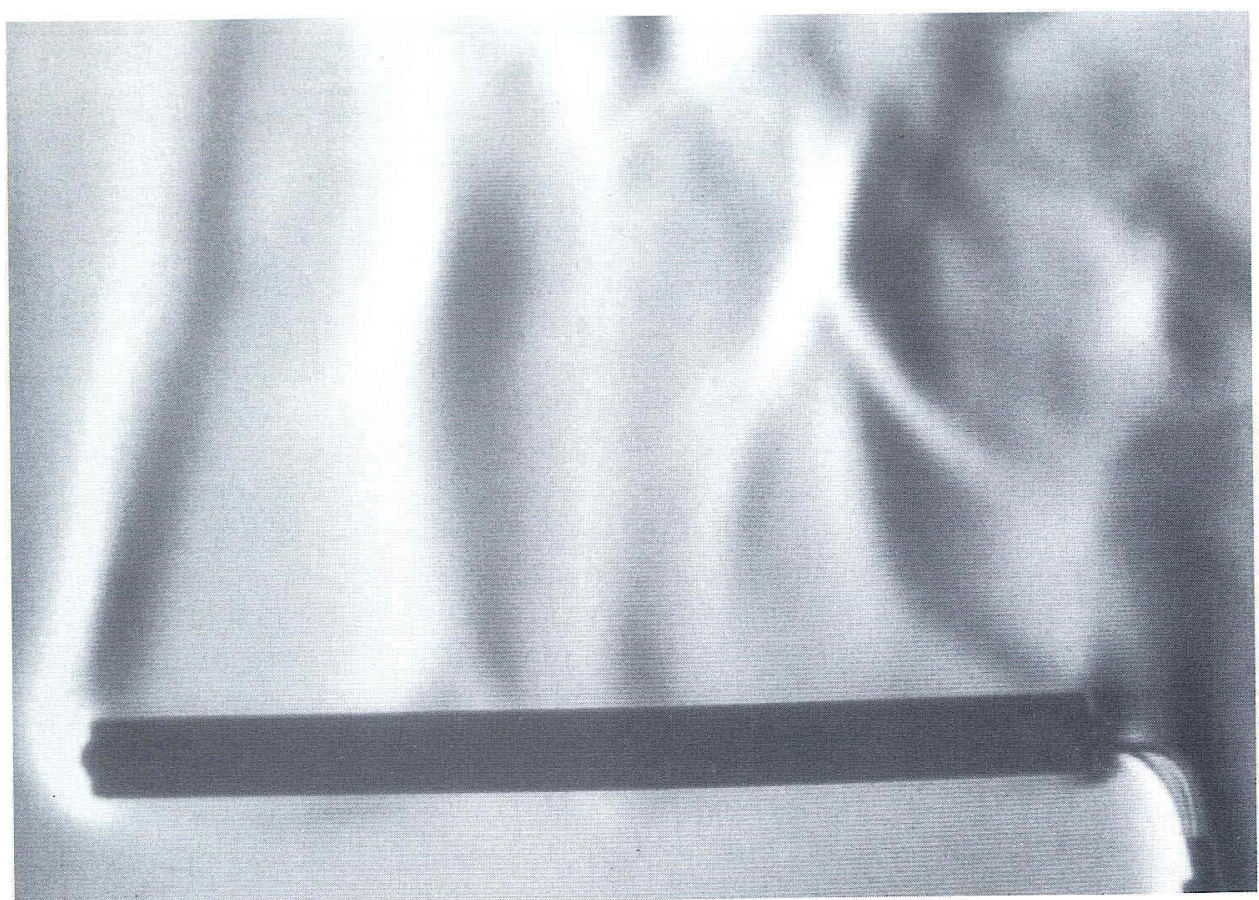


Figure 5.

Side view of a smoldering cigarette taken with the schlieren system.

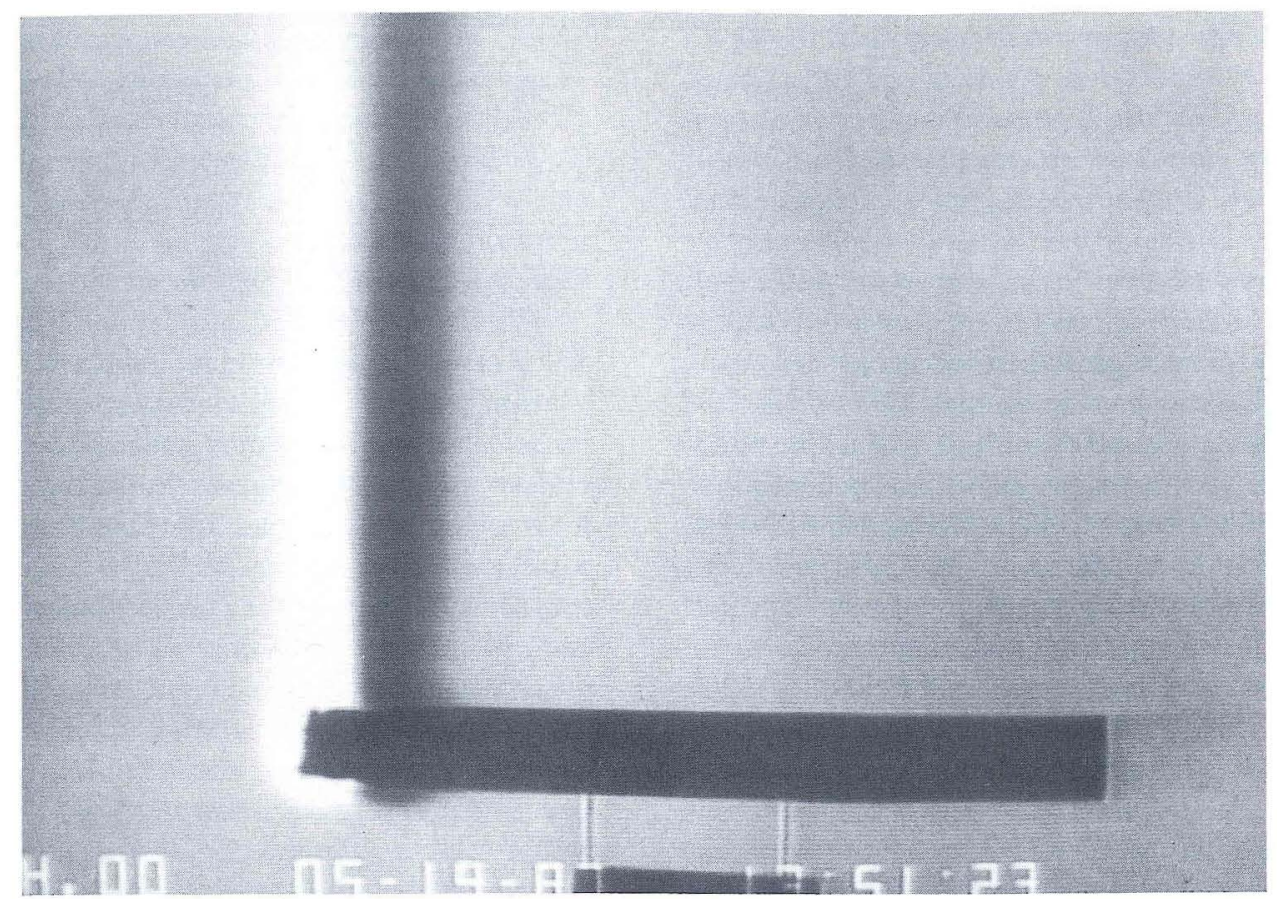

refractive index gradient changes sign from negative to positive, the image changes from light to dark forming the line in the image.

The thermal column rising from a cigarette has been compared to the thermal convection currents caused by a heated cylinder $(6,7)$. However, a cigarette has only a relatively short section heated at any one time. Figure 4 shows the side view of a heated cylinder in the schlieren field. Comparing this with the side view of a burning cigarette in the schlieren field, shown in Figure 5, one can immediately see the differences. The image of the heated cylinder reveals a considerable amount of turbulence in the rising convection currents along the entire length of the cylinder. The image of the cigarette, however, shows a well-defined convection column with no apparent turbulence located over the cigarette coal. Comparing the endon view of a heated cylinder in Figure 6 with the end-on view of a burning cigarette in Figure 7 , one can see that the patterns now appear quite similar. Perhaps the more correct way of stating the comparison would be to say that the flow field of the thermal column rising from a cigarette coal in a plane normal to the rod axis (end-on view) is similar to that of a heated cylinder. To assume that the flow fields along the axis are similar may lead to errors. The heat of the coal is sufficient to account for the formation and behavior of the schlieren image. The gases generated by the combustion process appear to play a small, if any, part. RoBinson has addressed this point in considerable detail in his paper (7). Also, this point is shown in the images of the methane gas jet when it is lit (Figure 3) compared to when it is not lit (Figure 2). The schlieren effect for the gas jet is small compared to that of the flame.
The combined schlieren and visual image for a 2R1 cigarette is shown in Figure 8. The picture was taken when the paper char line was nearing the $20 \mathrm{~mm}$ mark on the cigarette rod. The schlieren half of the image shows that the thermal convection column is centered $2 \mathrm{~mm}$ in front of the paper char line while the visual half shows that the smoke plume is centered $2 \mathrm{~mm}$ behind the char line. The smoke plume rises in a well-defined column about $4 \mathrm{~mm}$ wide with one outside edge even with the paper char line. The thermal column is also well defined and is centered over the hottest part of the smoldering coal as determined by infrared imaging $(10,11)$. Examination of the video images for many $2 \mathrm{R} 1$ cigarettes showed only slight variations in the positions of the two columns.

Combined schlieren and visual images for cigarettes with 12, 23 and $48 \mathrm{~cm} / \mathrm{min}$ (CoResta) porosity papers are presented in Figures 9, 10 and 11, respectively. These images show little variation in the position of either column as a function of paper porosity. BAKER has commented that there is no change in the position of the smoke plume as a function of paper porosity because the paper behind the paper char line has started to decompose opening large pores for the escape of the materials that will condense to form the smoke plume $(6,12)$. This system was not designed to measure the amount of sidestream smoke produced by a cigarette. However, a relative ranking of the amount of smoke from each cigarette could be made by comparing the brightness and thickness of the sidestream smoke plumes. Comparing Figures 9, 10 and 11 shows that paper porosity does have an effect on the emission of sidestream smoke. The less porous the paper, the less smoke appears to be produced. Figure 12 shows a representative image for the cigarettes 
Figure 6.

Schlieren image of a heated cylinder viewed end on.

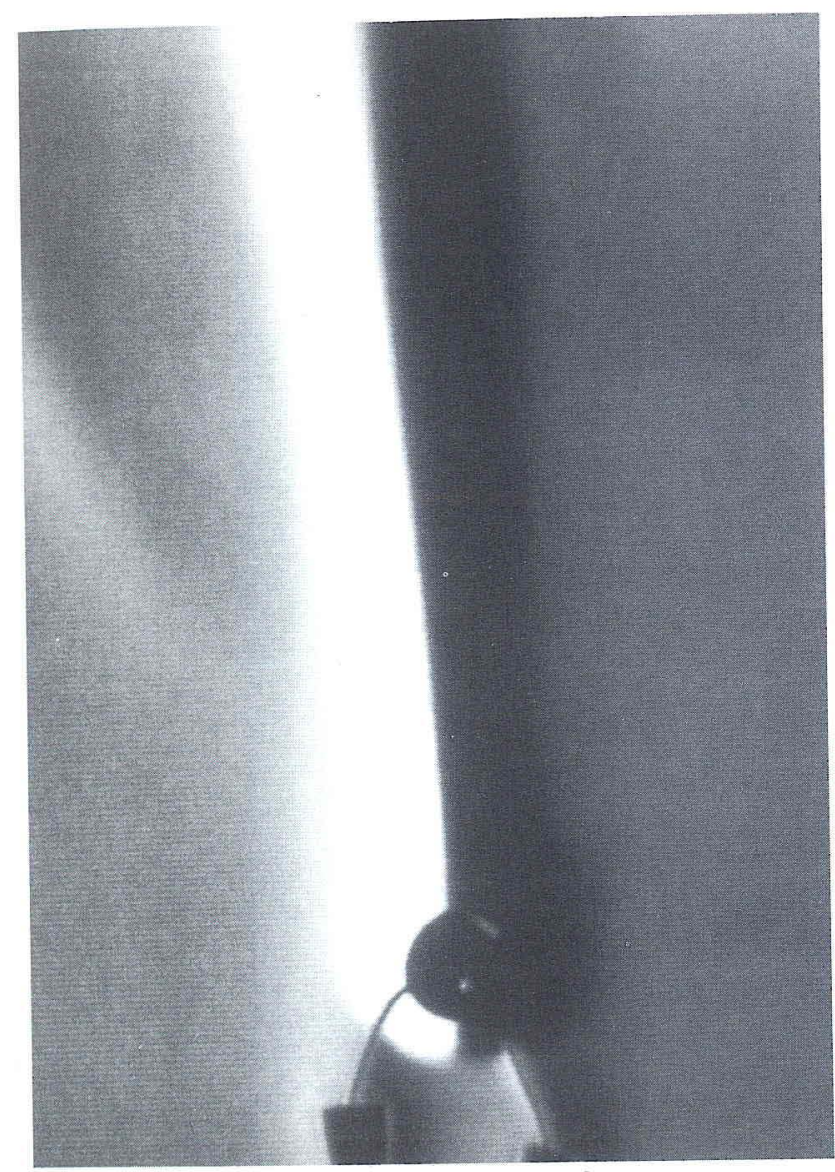

Figure 7.

Schlieren image of a smoldering cigarette viewed end on.

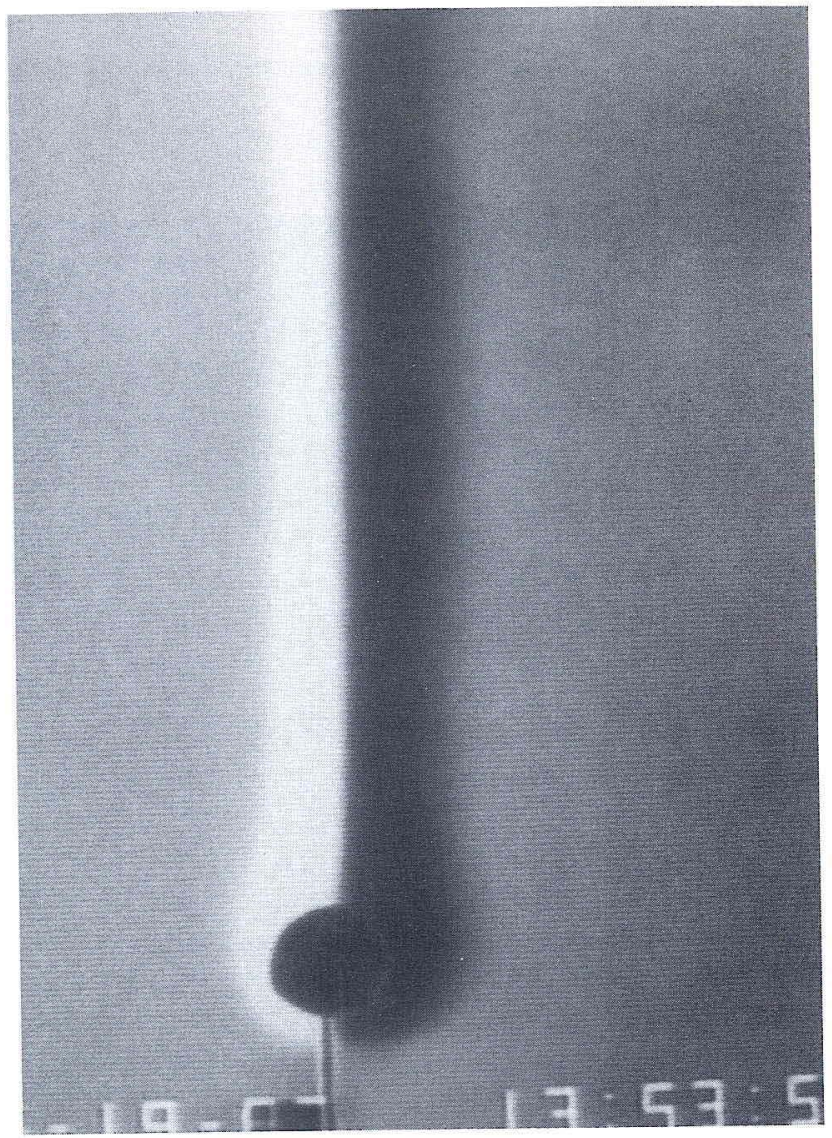

Figure 8.

Combined schlieren (left side) and visual (right side) image of a smoldering 2R1 cigarette. Note that the thermal convection column is centered $2 \mathrm{~mm}$ in front of the paper char line while the smoke plume is centered $2 \mathrm{~mm}$ behind this line.

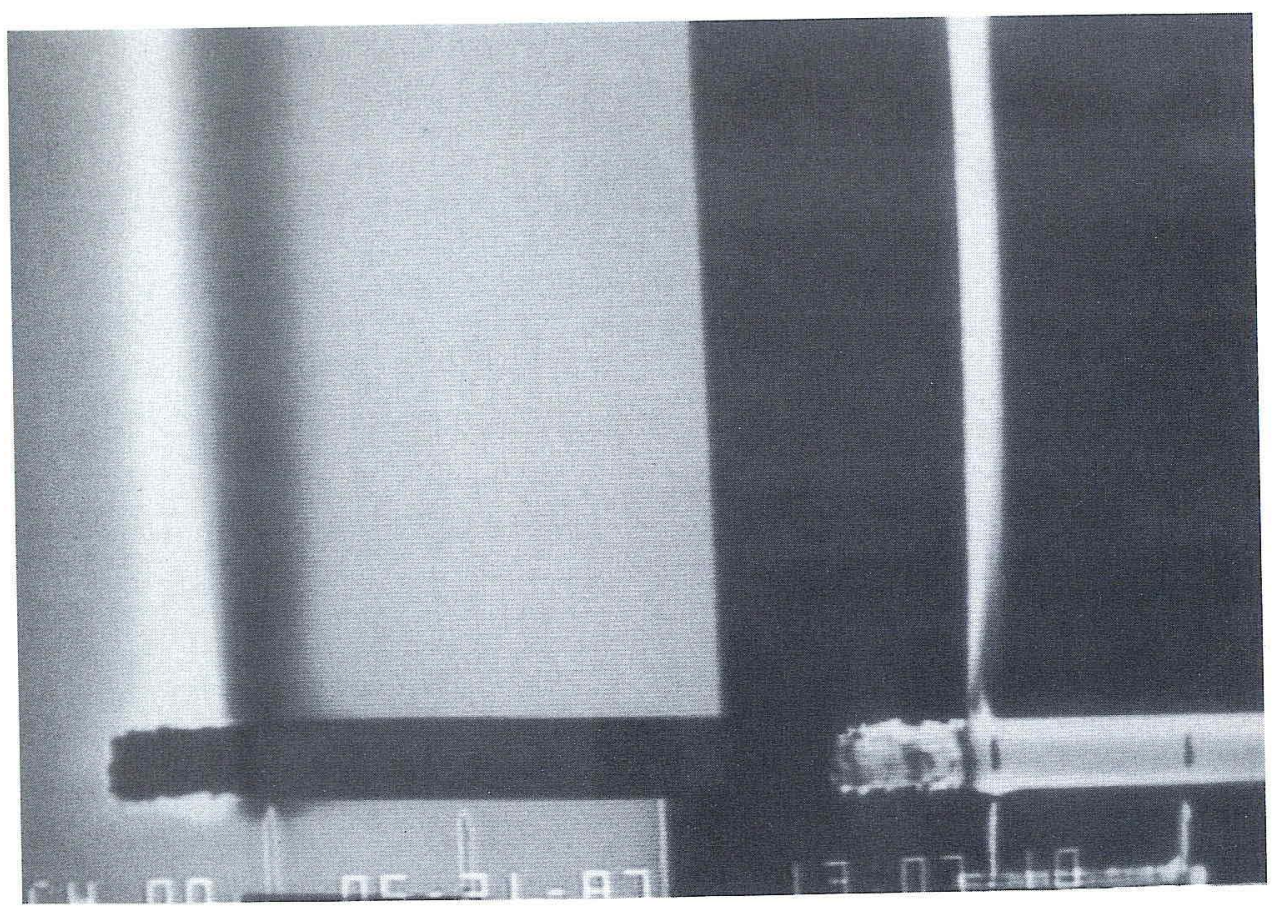


Figure 9.

Combined schlieren and visual image of an experimental cigarette wrapped with a paper having a porosity of $12 \mathrm{~cm} / \mathrm{min}$.

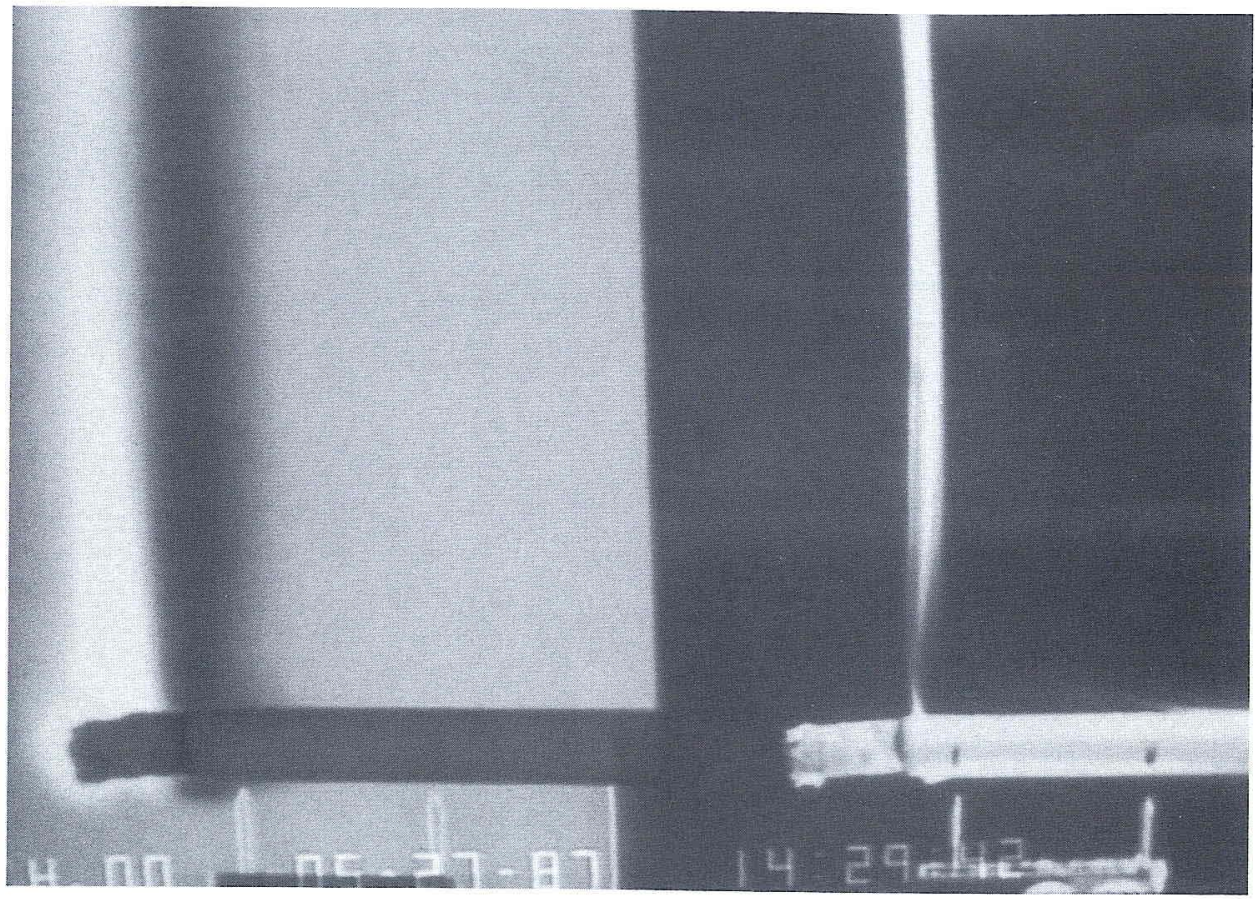

Figure 10.

Combined schlieren and visual image of an experimental cigarette wrapped with a paper having a porosity of $23 \mathrm{~cm} / \mathrm{min}$.

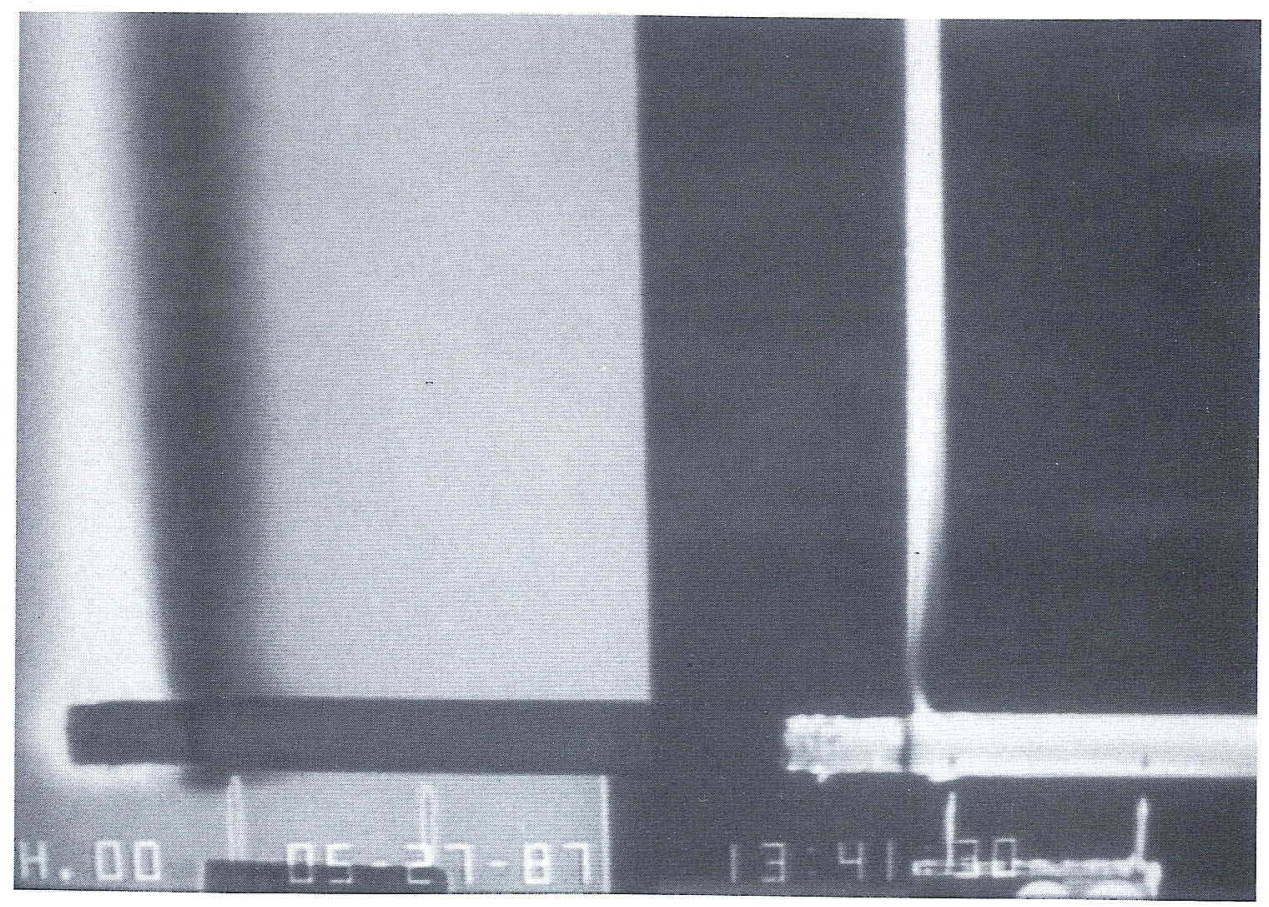


Figure 11.

Combined schlieren and visual image of an experimental cigarette wrapped with a paper having a porosity of $48 \mathrm{~cm} / \mathrm{min}$.

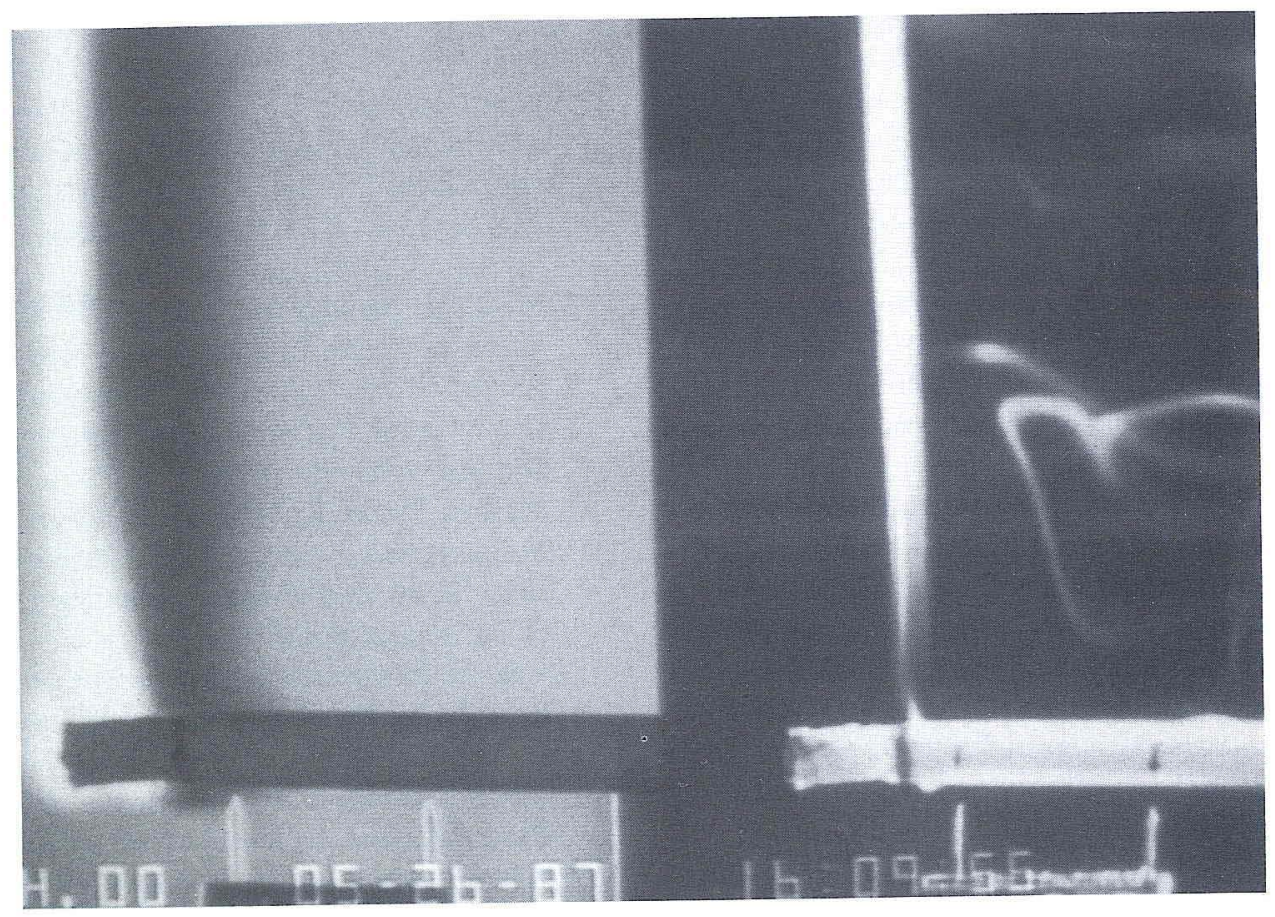

Figure 12.

Combined schlieren and visual image of an experimental cigarette wrapped with a paper designed to reduce the amount of sidestream smoke. The paper had a $\mathrm{Mg}(\mathrm{OH})_{2}$ based inorganic filler and a porosity of $17 \mathrm{~cm} / \mathrm{sec}$.

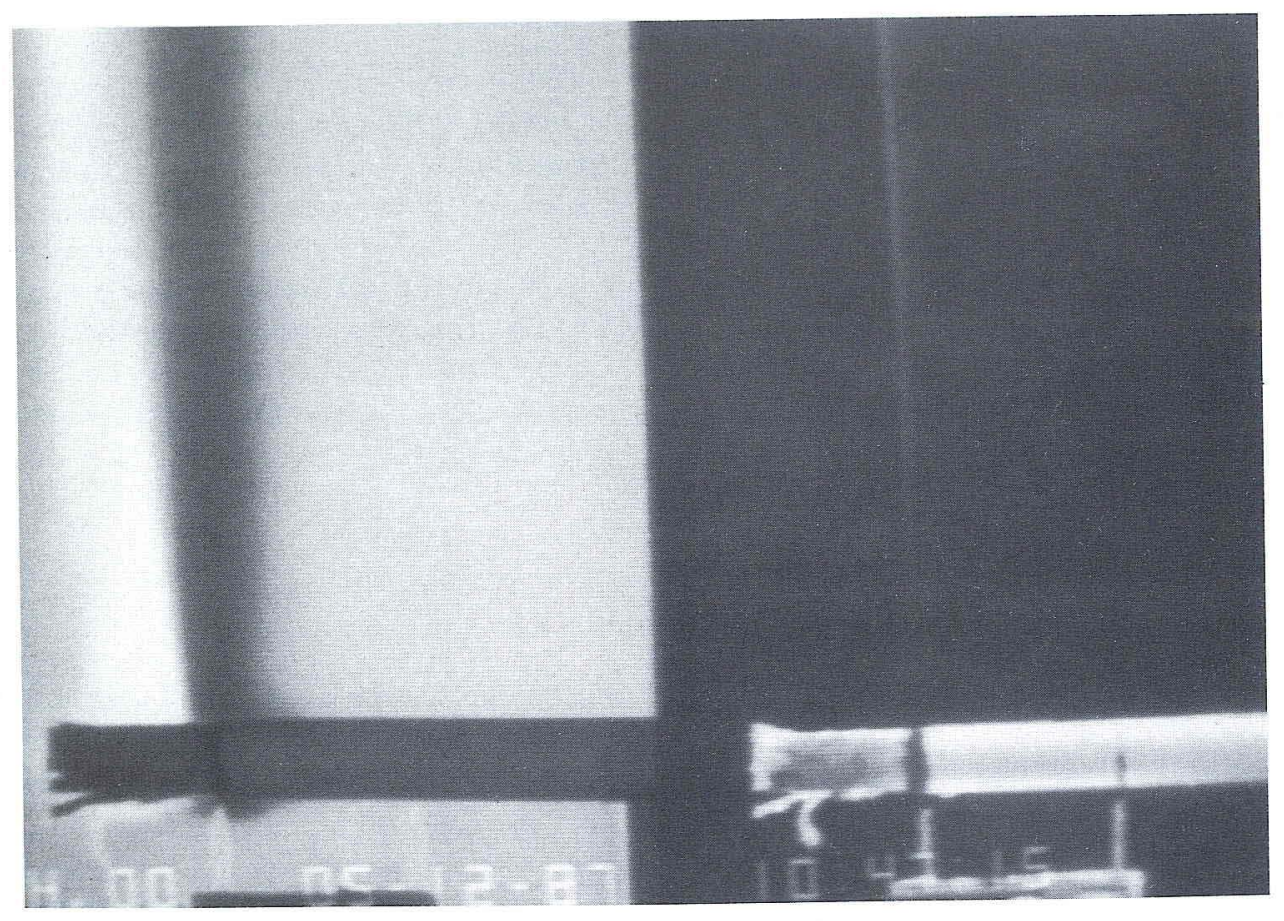


made from paper with a $\mathrm{Mg}(\mathrm{OH})_{2}$ based inorganic filler. The thermal convection column position has not changed. However, there is a marked change in the position and appearance of the smoke plume. It is now quite faint and is positioned directly over the paper char line.

The observations made in this study allow some interesting speculations on the mode of action of $\mathrm{Mg}(\mathrm{OH})_{2}$ based low sidestream papers. Arguably, they do not reduce sidestream smoke solely through the mechanism of decreased initial paper porosity. If this was the only mechanism present then the smoke plume should still be located $2 \mathrm{~mm}$ behind the paper char line. Rather, it seems that the $\mathrm{Mg}(\mathrm{OH})_{2}$ must act to prevent the formation of large pores when the paper starts to decompose behind the char line or it acts to block these pores. In either event the smoke forming condensibles are forced by internal pressure to exit the cigarette where the paper has finally broken down at the paper char line. Here the escaping materials are subjected to increased heat leading to further pyrolysis and combustion so there is less material suitable to condense to form smoke. In addition, the remaining condensibles are released into a hotter and faster rising gas stream. This serves to reduce smoke formation by suppressing condensation and increasing dilution. All of these processes would reduce the amount of visible smoke produced. The contribution of each process should be the subject of further research.

\section{REFERENCES}

1. Coresta Standards: The smoke yield of a tobacco product, cigarette definitions and measuring principles; Coresta Information Bulletin 4 (1962) 5-8.

2. Lipp, G.: Zur Definition der Selektivität und der verschiedenen Rauchströme der Cigarette; Beitr. Tabakforsch. 3 (1965) 220-222.

3. Seehofer, F, D. Hansen, H. Rabit, and R. Schroder: Über den Verbleib des Wassers beim Abrauchen; Beitr. Tabakforsch. 3 (1966) 491-503.
4. Neurath, G., H. Ehmke, and H. Schneemann: Über den Wassergehalt von Haupt- und Nebenstromrauch; Beitr. Tabakforsch. 3 (1966) 351-357.

5. Ayer, H. E., and D. W. Yeager: Irritants in cigarette smoke plumes; Amer. J. Public Health 72 (1982) 1283-1285.

6. Baker, R. R.: Variation of sidestream gas formation during the smoking cycle; Beitr. Tabakforsch. Int. 11 (1982) 181-193.

7. Robinson, D. P.: Aerodynamic characteristics of the plume generated by a burning cigarette; in Proceedings of the International Conference on the Physical and Chemical Processes Occurring in a Burning Cigarette, R. J. Reynolds Tobacco Co., WinstonSalem, NC, 1987, pp. 115-150.

8. Schlieren photography; KODAK Publication P-11, Eastman Kodak Co., Rochester, NY, 1977.

9. Barnes, N. F, and S. L. Ballinger: Schlieren and shadowgraph equipment for air flow analysis; J. Opt. Soc. Amer. 35 (1945) 497-509.

10. McRae, D. D., R. W. Jenkins, Jr., and J. S. Brenizer: Measurement of temperature distributions of cigarette coals by infrared imaging radiometry; in Proceedings of the International Conference on the Physical and Chemical Processes Occurring in a Burning Cigarette, R. J. Reynolds Tobacco Co., Winston-Salem, NC, 1987, pp. 62-75.

11. McRae, D. D., R. W. Jenkins, and J. S. Brenizer: Assembly and calibration of an infrared imaging system for the study of temperature distributions in cigarette coals; CoResta '86, Taormina, Italy, October, 1986.

12. Baker, R. R.: Variation of the Permeability of Paper with Temperature; Tappi 59 (1976) 114-115.

Authors' address:

Philip Morris U.S.A.,

Research and Development,

P.O. Box 26583,

Richmond, VA 23261, U.S.A. 